\title{
Making Coasean Property More Coasean
}

\author{
Thomas W. Merrill Columbia University \\ Henry E. Smith Harvard University
}

\begin{abstract}
In his pioneering work on transaction costs, Ronald Coase presupposed a picture of property as a bundle of government-prescribed use rights. Not only is this picture not essential to Coase's purpose, but its limitations emerge when we apply Coase's central insights to analyze the structure of property itself. This leads to the Coase corollary: in a world of zero transaction costs, the nature of property does not matter to allocative efficiency. However, as with the Coase theorem, the real implication is for our world of positive transaction costs: we need to subject the notion of property to a comparative institutional analysis. Because transaction costs are positive, property is initially defined in terms of things, uses are grouped under exclusion rights, and in rem rights are widely employed. A more thoroughly Coasean approach points back to a picture of property more like the traditional one furnished by the law.
\end{abstract}

\section{Introduction}

More so than any other modern thinker, Ronald Coase has had a profound impact on the study of property rights. There is an irony and a paradox in this. The irony is that Coase never intended to have such an impact. As he has said, most recently in the video interview that introduced the Coase Centennial Conference, his scholarly objective was to illuminate the impact of the legal system on the working of the economy, not to advance our understanding about how economic forces may influence the law (Coase 1988). The paradox concerns the role of Coase's presuppositions about property. In his seminal writings, Coase

The authors thank Benito Arruñada, Yun-chien Chang, Bob Ellickson, Tom Hazlett, and an anonymous reviewer as well as participants at the conference Markets, Firms, and Property Rights: A Celebration of the Research of Ronald Coase, University of Chicago School of Law (December 45, 2009); participants at the International Society for New Institutional Economics 14th annual conference, University of Stirling (June 17-19, 2010); and participants at the Italian Society for Law and Economics workshop Deconstructing Coase, University of Bolzano (December 9, 2010). All errors are the authors' own. 
assumes a picture of property as ad hoc bundles of government-prescribed use rights. This assumption is deeply misleading in critical respects and is out of sync with both classical and much contemporary economic thought. However, not only is Coase's picture of property not essential to what Coase was trying to do, its limitations emerge when we apply Coase's central insights to analyze the structure of property itself.

To see how Coasean analysis yields a conception of property at odds with Coase's own picture of property, we introduce in Section 5 the Coase corollary: in a world of zero transaction costs, wealth maximization will occur regardless of the nature and scope of property rights. Like the Coase theorem itself, the Coase corollary is a thought experiment. It does not purport to describe the real world, where positive transaction costs are pervasive. In a world of positive transaction costs (in the broadest sense of institution costs and not just the costs of exchange), the system of property rights surely does matter. In such a world, a system in which use rights are assigned by the state in an ad hoc, resourceby-resource fashion would operate at a severe disadvantage, because of the high transaction costs this system would impose on participants in the economy. By contrast, a system in which use rights come in a relatively small number of prescribed packages would present significantly lower transaction costs. In effect, the Coase corollary leads us to a picture of property more like the traditional one furnished by the law.

What is needed to explain the nature of property is no different from what Coase advocates more generally for transaction cost economics: comparative institutional analysis. This is the paradox of Coasean property: Coase's picture of property is not what one would expect to find, given a rigorous application of Coase's own methodology.

\section{The Influence of Coase on Our Notion of Property}

Before we isolate the limits of Coase's picture of property, it is important to recognize some of the many ways in which Coase has influenced our understanding of property. A complete catalog of influences would be nearly impossible. We highlight five developments in property theory, each of which can be traced to Coase's seminal midcareer work, most importantly "The Problem of Social Cost" (Coase 1960).

First, Coase's insight that externalities can be internalized by contractual exchanges of property rights formed the foundation of the new institutional approach to property rights. In particular, Demsetz (1967), picking up where Coase left off his discussion, perceived that externalities can also be internalized by creating new property rights where none previously existed. Coase saw that proposed contracts to modify rights (whether such proposals are accepted or rejected) cause actors to take account of how their actions with respect to resources affect others; through this process, contractual exchange of rights can 
lead to the use of resources that maximizes social value. Demsetz saw that new arrangements of property rights, especially the creation of property rights in previously open-access resources, bring home to owners how their actions with respect to these resources affect the valuation that others place on those resources. The emergence of property rights thus tends toward a use of resources that maximizes social value. This Demsetzian variation on the original Coasean logic gave rise to a powerful economic theory explaining the evolution of property rights over time. ${ }^{1}$

Second, Coase's emphasis on the importance of transaction costs in determining the structure of economic institutions carried with it implications for the protection of entitlements. Very Coasean in spirit is the work of Calabresi and Melamed (1972), with its landmark distinction between property rules and liability rules as modes of protection of property rights. Property rule protection permits the transfer of rights only with the consent of the rights holder, typically through voluntary exchange. Liability rule protection permits the transfer of rights without the consent of the rights holder, conditioned on the payment of government-determined compensation for the rights taken. The principal explanation given by Calabresi and Melamed for the turn to liability rules in various contexts was high transaction costs. In other words, when transaction costs make it difficult to reallocate entitlements through consensual transactions and/or litigation, this supplies a justification for switching from property rule to liability rule protection to achieve allocative efficiency (Calabresi and Melamed 1972, pp. 1106-7). This is a direct application of Coase's central insight about the critical role of transaction costs, deployed here as an explanation for an important feature of the structure of legal rights.

Third, Coase's emphasis on the importance of transaction costs in determining whether rights will be exchanged stimulated a number of insights into how legal institutions are designed to facilitate transactions. Examples include the use of rules rather than standards in defining property rights (Merrill 1985, p. 16), the use of rectilinear rather than meandering property boundaries (Libecap and Lueck 2011), the adoption of land titling and registration systems (Arruñada 2003), and the importance of the numerus clausus in limiting the number of property forms (Merrill and Smith 2000). In each case, the starting point of the inquiry has been the assumption that the ability to exchange rights is of central importance to achieving a more efficient use of resources, and that this is reflected in the structure of rights. This starting point in explaining many features of the structure of property systems is directly attributable to the Coasean perspective.

Fourth, Coase's emphasis on the importance of exchange of rights has underscored the importance of concentrating ownership of property in a way that facilitates transfer. This has led to a variety of additional insights about the

\footnotetext{
${ }^{1}$ For a collection of papers exploring, extending, and critiquing the Demsetzian perspective on the evolution of property rights, see Supplement: The Evolution of Property Rights (Journal of Legal Studies 2002).
} 
structure of rights, such as why rules for establishing original ownership of resources assume a winner-take-all form (Epstein 1979b, pp. 1222-23; Rose 1997, p. 2179; Merrill 2009, p. 463), the need for maintenance doctrines that militate against excessive fragmentation of rights over time (Heller 2008), and even the advantages of using trusts in transferring property from one generation to the next because legal title is concentrated in a single trustee (Merrill and Smith 2001a, pp. 848-49).

Fifth, Coase's insistence on comparing the performance of different institutions in regulating externalities, including market transactions and government regulation, has grown into the New Institutional Economics (Williamson 1975; Barzel 1997, pp. 3-4, 11; Eggertsson 1990, p. 33; Alston 2008, pp. 32-37). In particular, the Coasean approach to institutional analysis has inspired subsequent literature on land use controls (Ellickson 1973), as well as a broader literature about the need for comparative institutional analysis in pursing any collective goal (Komesar 1994). In this sense, Coase can be said to be the father of comparative institutional analysis, at least in the literature inspired by economics.

Obviously, this is, by any measure, an extraordinary-indeed, a stunninglegacy for one thinker. The focus on externalities, the possibility of reducing externalities through exchange of rights, the role of transaction costs in determining the feasibility of exchange of rights, and the need for measuring proposals for regulation against the benchmark of exchange of rights-these ideas were transformative. Coase's cluster of ideas, either singularly or in combination, have had a revolutionary impact on our collective understanding of property rights.

\section{Coase's Picture of Property}

Throughout his writings, but especially in his highly influential papers "The Federal Communications Commission" (Coase 1959) and "The Problem of Social Cost" (Coase 1960), Coase presupposed a particular picture of property: that of property as a bundle of rights or, more precisely, as a collection of use rights authoritatively prescribed by the state for each resource (Merrill and Smith 2001b). This picture of property is by no means unique to Coase. Indeed, the idea of property as a bundle of government-prescribed use rights was a thoroughly modern notion when Coase wrote his seminal articles. ${ }^{2}$

Before Coase's time-that is, 100 years ago and more-a different picture of property prevailed in legal and economic literature (Merrill and Smith 2001b, pp. 360-66, 383-84). This was the picture of property as a kind of minisovereignty. According to this picture, to be an owner is to be the ruler over some thing. Just as the king was understood to be the ruler of the realm, so the owner

\footnotetext{
${ }^{2}$ The bundle-of-rights picture was the overwhelming consensus view among commentators of the mid- to late twentieth century. For example, Ackerman (1977, pp. 26-29) reports that the bundleof-rights conception of property is so pervasive that "even the dimmest law student can be counted upon to parrot the ritual phrases on command." See also footnote 3 and accompanying text.
} 
of property was the ruler over some Blackacre or chattel within the realm. William Blackstone, a master synthesizer of conventional wisdom, expressed the idea quite directly. Property, he said, is that "sole and despotic dominion which one man claims and exercises over the external things of the world, in total exclusion of the right of any other individual in the universe" (Blackstone 1979 [1766], p. $\left.{ }^{\star} 2\right)$.

The notion of property as a type of sovereignty was an exaggeration, as Blackstone himself seems to have been aware (Burns 1985; Rose 1998, p. 604; Schorr 2009). Regulation, taxation, and liability for uses of property that harm others always constrained the discretion of property owners. However, the picture of property as sovereignty had one great virtue. It captured the idea that property rights are in rem, meaning that property rights create duties of noninterference in all persons.

The distinctive feature of rights in rem is best understood in contrast to the features of rights in personam. In personam rights, such as rights created by contract or by judgment, attach to specific individuals and are paired with duties in other specific individuals. Thus, if A promises to deliver widgets to B in return for cash, A and B have specific rights that are defined in terms of specific duties that they owe to each other-either to deliver the widgets or the cash. Similarly, if $C$ obtains a restraining order against $D, C$ 's rights to be free of interference by $\mathrm{D}$ and D's duties to desist from interfering with $\mathrm{C}$ are defined with respect to and are specific to each other.

In rem rights, in contrast, are rights that create duties of noninterference in all other persons, not just in specifically identified others. Individual rights of bodily integrity, reputation, and privacy protected by the law of tort are in rem rights in this sense. Similarly, property rights are in rem, in that they create duties of noninterference with things marked in conventional ways as being owned, which duties apply as a matter of law to all persons. Thus, if Blackacre is marked as an owned thing-perhaps because it has a fence or hedge around it-all other persons are subject to a duty not to invade Blackacre without permission of the owner. This duty applies without regard to who the owner of Blackacre happens to be, or the form of ownership in which it is held, or what uses the owner has in mind for Blackacre. Similar legally imposed duties of noninterference apply to personal property, such as cars, and to intellectual property rights, such as patents and trademarks, identified in conventional ways as being owned.

The understanding of property as a right in rem creating a duty of noninterference in all persons was not unique to Blackstone and his description of property as the "sole and despotic dominion" of one person over some thing. It has been a fixture of all legal systems that trace at least part of their heritage to Roman law. It also can be found in the writings of many of the founders of modern economics, including Smith ([1762-63] 1978) and Jeremy Bentham (Bentham 1945, p. 164; Bentham [1782] 1970, pp. 177-78).

At about the time that Coase embarked on his academic career, the traditional 
picture of property as a kind of minisovereignty came under attack, most notably from a group of American academics known as the Legal Realists. ${ }^{3}$ The Realists offered a competing picture of property - that of property as a bundle of rights or sticks. The idea is that property is simply a label attached to a collection of rights and obligations associated with particular things. The number and identity of the sticks vary from thing to thing, from place to place, and even from person to person. The content of the bundle is determined collectively-that is, primarily by the state through its laws.

The Legal Realists' motivation for advancing the bundle-of-rights picture was political (Grey 1980; Fried 1998). The Realists sought to deprivilege property, as the postmodernists would say (although "dethrone" might be a more appropriate expression in this context), to facilitate more extensive collective control over property, especially through programs of redistribution.

However, the bundle-of-rights picture had a side effect, quite possibly unintended, in that it obscured the in rem character of property rights. The minisovereign picture puts the in rem feature front and center. Just as everyone in the realm owes a duty of obedience to the king without regard to whether they have personally sworn allegiance to the king, so everyone owes a duty of noninterference to the owner of property, whether or not any one of them has met the owner or promised to respect the owner's rights to the owned thing. Also, just as the king has very broad discretionary authority in determining what happens in the realm (at least in the days before parliamentary democracy appeared on the scene), so the owner of property has very broad discretionary authority in determining how owned things are used.

The bundle-of-rights picture is not logically incompatible with the understanding that property rights are in rem. However, it has a strong tendency to obscure the in rem feature of property. If property rights can be adjusted along countless margins, often in the course of the rendering of specific judgments by courts, then it becomes natural to start to think of property as a kind of master list of rights and duties set forth by some authoritative state institution for each type of property or indeed for each particular parcel of property. Under the bundle picture, property becomes an elaborate catalog of in personam rightssetting forth what the owner can or cannot do and, concomitantly, determining what others can and cannot do with respect to specific resources-established by the state either through legislation or litigation (Merrill and Smith 2001b, p. 366). The right/duty relationship no longer runs between the owner and the world, but between the owner and the state.

Coase, being a man of his times_-and, one might add, being someone with

\footnotetext{
${ }^{3}$ For a prominent statement, see Cohen (1935, pp. 839-42). The roots of this conception of property can be traced to the work of Wesley Newcomb Hohfeld, although he did not use the metaphor of a bundle of sticks (Corbin 1922, p. 429; Radin 1938).
} 
little interest in legal concepts ${ }^{4}$ - wholeheartedly embraced the bundle-of-rights picture as his understanding of property. Of course, Coase had little sympathy with the Legal Realist agenda of enhancing collective control or redistribution of property. Coase was interested in promoting the idea of contractual exchange of rights as an alternative to collective regulation. Nevertheless, he adopted the picture of property as a list of permitted and proscribed uses imposed by the authoritative institutions of the state. In so doing, he, like the Realists, obscured the crucial in rem feature of property rights.

The evidence for Coase's embrace of the bundle-of-rights picture of property is primarily based on what Coase says in his seminal 1959 and 1960 articles. We will provide here only a few select quotations from those works. Those interested in a more complete documentation of evidence based on these articles should consult an essay we wrote that also touches on Coase's influence on property scholarship (Merrill and Smith 2001b).

Consider, first, a passage that appears on the last page of "The Problem of Social Cost" (Coase 1960, p. 44):

The rights of a land-owner are not unlimited. It is not even always possible for him to remove the land to another place, for instance, by quarrying it. And although it may be possible for him to exclude some people from using "his" land, this may not be true of others. For example, some people may have the right to cross the land. Furthermore, it may or may not be possible to erect certain types of buildings or to grow certain crops or to use particular drainage systems on the land. This does not come about simply because of Government regulation. It would be equally true under the common law. In fact it would be true under any system of law. A system in which the rights of individuals were unlimited would be one in which there were no rights to acquire.

The conclusion that Coase draws from these observations is quite striking: "We may speak of a person owning land and using it as a factor of production but what the land-owner in fact possesses is the right to carry out a circumscribed list of actions" (Coase 1960, p. 44). This passage rather clearly indicates that Coase understood property not as any distinctive right to a thing imposing duties of noninterference on all others but rather as a bundle or collection of rights to perform or desist from certain actions with respect to resources.

Even more striking is the discussion in the 1959 article on the Federal Communications Commission, which served as a precursor to the more famous article on social cost published the next year. In that article, Coase was directly concerned with making the case for establishing a market in rights to the use of radio spectrum frequencies, or what might loosely be termed "spectrum rights." The nature of property rights was more central to this project than to the more influential article on social cost.

In making the case for allocating spectrum rights by contract, Coase had to

\footnotetext{
${ }^{4}$ Coase (1960, p. 15) describes the reasoning of the judges in resolving nuisance cases as frequently resting on factors that seem "strange to an economist," such as the doctrine of the lost grant, which he says is "about as relevant as the colour of the judge's eyes."
} 
confront a variety of arguments to the effect that private property rights in the radio portion of the electromagnetic spectrum are too difficult to define and enforce, given the invisible nature of the resource and our limited understanding of the circumstances in which one type of use of the radio spectrum will interfere with another. Coase sought to address these concerns by suggesting that privatization of spectrum rights should proceed not by defining exclusive rights in a portion of the "ether" or in particular radio frequencies, but rather by specifying use rights in broadcasting equipment. He summarized his position as follows Coase (1959, p. 33): "What does not seem to have been understood is that what is being allocated by the Federal Communications Commission, or, if there were a market, what would be sold, is the right to use a piece of equipment to transmit signals in a particular way. Once the question is looked at in this way, it is unnecessary to think in terms of ownership of frequencies or the ether."

Lest there be any ambiguity about Coase's preference for defining the proposed property rights in terms of permitted uses of broadcasting equipment, he immediately turned to certain suggestions that rights to radio spectrum frequencies could be determined by analogy to air rights over land. Coase (1959, p. 34) thought that this way of thinking of the problem "tends to obscure the question that is being decided." He continued, "[W] hether we have the right to shoot over another man's land has been thought of as depending on who owns the airspace over the land. It would be simpler to discuss what we should be allowed to do with a gun" (p. 34). Coase's preference for defining property rights in terms of permitted uses was here revealed in the starkest possible terms. Coase thought it was unduly complicated to try to describe the rights of a landowner in terms of a general rule about the right of the owner to exclude intrusions by strangers from a delimited space-the traditional in rem approach. Far better to draw up a list of permissible uses of a gun.

Two other features of these articles, especially the 1960 article "The Problem of Social Cost," reinforced the list-of-uses or bundle-of-rights picture of property. First, all of Coase's examples involved two-party disputes: ranchers and farmers, doctors and confectioners, and so forth. ${ }^{5}$ This made it more plausible to imagine property as a list of use rights freely exchangeable between the parties to any dispute. Cattle could be allowed to trample crops, or cattle could be prohibited from trampling crops (either way), and the rancher and farmer would then decide how to reallocate this use right. Second, all of Coase's examples involved land use incompatibilities, usually incompatibilities considered under the rubric of nuisance law. This made it more plausible to think of use rights as being

\footnotetext{
${ }^{5}$ See Coase (1960), discussing Sturges v. Bridgman, 11 Ch. D. 852 (1879), which involved a confectioner and a doctor (pp. 8-10); discussing Cooke v. Forbes, L.R. 5 Eq. 166 (1867-68), which involved a mat weaver and an ammonia manufacturer (pp. 10-11); discussing Bryant v. Lefever, 4 C.P.D. 172 (1878-79), which involved an owner of a house with timber stacked on the roof and an owner of an adjacent house with a smoky chimney (pp. 11-13); discussing Bass v. Gregory, 25 Q.B. D. 481 (1890), which involved the owners of a public house with a brewing vat and an owner of some cottages with a well that served as a ventilating shaft for the vat (p. 14).
} 
highly mutable. Had Coase focused on other problems associated with ownership, such as physical ouster, theft, or state expropriation, this perspective would not have seemed so plausible.

We now know that Coase's seminal contributions in his 1959 and 1960 articles occurred at the midpoint in his extraordinary career. Coase's endorsement of the bundle-of-rights picture of property in these articles would have had little influence on subsequent property scholarship if he had recanted this feature of his analysis in later writing. There is, however, no evidence that Coase ever relinquished his attachment to the bundle-of-rights picture of property. In fact, three pieces of evidence from Coase's later writings appear to confirm his lifetime commitment to this viewpoint.

Tom Hazlett has suggested in conversation that Coase abandoned the bundleof-rights picture and embraced a more conventional in rem conception of property, in a draft study he undertook in 1963 for the RAND Corporation on the allocation of the radio spectrum. ${ }^{6}$ RAND commissioned the study to examine how the nascent federal space program could acquire sufficient spectrum rights to ensure adequate communications between satellites or spacecraft and ground controllers. The draft was authored by Coase and two RAND economists, William Meckling and Jora Minasian. The lengthy draft covers a variety of topics related to the space communications issue, and it includes as a solution to anticipated spectrum shortages two chapters proposing that spectrum rights should be allocated by market transactions rather than by government fiat. This, of course, is the proposal advanced by Coase in his 1959 article "The Federal Communications Commission."

Interestingly, the two chapters set forth two different analyses of how units of spectrum rights could be defined as a predicate to establishing a functioning market in such rights. The first of these chapters, chapter 3 in Coase, Meckling, and Minasian (1995), entitled "The Radio Frequency Spectrum as a Scarce Resource," suggests that property rights be defined in terms of inputs, defining the permissible uses of broadcasting equipment. This is precisely the proposal advanced by Coase in his 1959 article. This chapter was clearly written by Coase. The draft in the chapter refers to the author in the first person as "I," and it introduces a quotation from the 1959 article with the phrase, "[a]s I said on a previous occasion" (Coase, Meckling, and Minasian 1995, p. 94). Not surprisingly, property in this portion of the draft study is treated as a bundle of authoritatively prescribed use rights. For example, at one point, the author of this chapter (Coase) says (Coase, Meckling, and Minasian 1995, p. 93), "We commonly think of the process of allocating radio frequencies as being similar to that by which a stone which is extracted from a quarry is allocated to various

\footnotetext{
${ }^{6}$ Although the draft study is undated, internal evidence suggests it was written in 1963 . The most recent material cited in the draft was published in 1962, and it refers to a conference held in 1963 in the future tense (see Coase, Meckling, and Minasian 1995, p. 11). For further discussion of the RAND study and Coase's role in the history of allocation of spectrum rights, see Hazlett, Porter, and Smith (2011).
} 
users. But, in looking at the question this way, we tend to forget that the stone can only be used in certain ways. What the owner of a piece of stone can do with it is strictly limited; but what he can do with it defines the property rights which adhere to ownership of a piece of stone. And the same would be true for the ownership of radio frequencies."

Chapter 4 of the draft study (Coase, Meckling, and Minasian 1995), entitled "Property Rights in Radiation: Alternative Approach," offered an alternative approach to establishing exchangeable rights in spectrum. This alternative conception would have defined the relevant units to be exchanged in terms of outputs-namely, in reference to a particular segment of bandwidth that could be broadcast over in a particular area-with the owner given a right to exclude all admissions by others into this frequency in this area. This alternative approach is squarely grounded in a conception of property as an in rem right of exclusionthe traditional legal understanding. The alternative analysis is written in an impersonal passive voice, cites primarily technical engineering materials, and adopts the style of a professional American academic journal. It was almost certainly written by one of Coase's coauthors, Minasian, who a decade later published an article (Minasian 1975) very similar to the alternative approach chapter in the RAND study.

The evidence from the draft study admittedly is not conclusive about Coase's views on property in the mid-1960s. The draft does not expressly acknowledge that different authors wrote the different chapters, nor does it acknowledge that there was any disagreement among the authors about the proper way to conceive of property rights in radio frequencies. Nevertheless, we believe that the draft study provides at least circumstantial evidence that Coase continued to adhere to his understanding of property as a bundle of use rights. The chapter that adopts the property-as-inputs conception refers to the author in the first person as Coase, and it clearly rehearses the Coasean view. The alternative approach grounded in exclusion rights bears no evidence of Coase's style of writing. It would not be uncommon for three authors of a consulting report to agree to disagree on a significant point like this by presenting their competing views as alternative ways of thinking about a problem. We strongly suspect that is what happened in the draft study.

Perhaps more to the point, even if Coase had experienced a conversion in 1963, this would have had little effect on readers of his seminal articles of 1959 and 1960. The draft study was suppressed by the RAND Corporation, evidently on the grounds that it was too controversial (Coase 1998, p. 579). Only many years later, in response to increased acceptance of the idea of allocating spectrum rights by market mechanisms, did RAND decide to make the study publicly available (Coase, Meckling, and Minasian 1995, p. iii). Even today, however, the draft study is not widely known or cited. Thus, the draft's implicit disavowal of Coase's picture of property, at least in its discussion of the alternative approach to establishing spectrum rights, had little or no influence on later development of property theory. 
The second piece of evidence is "The Lighthouse in Economics" (Coase 1974). Coase became interested in lighthouses because they have been widely cited in economics texts as an example of a public good that is nonexcludible and nonrivalrous, often with the accompanying suggestion that this means that lighthouse services must be provided by the government and funded using general tax revenues. Through an examination of the history of lighthouses in Britain, Coase was able to show that lighthouses have, at some times, been built and operated by nongovernmental entities. Thus, as Coase (1974, p. 376) correctly concluded, they are not "an example of a service which could only be provided by the government."

Coase (1974, p. 375) also thought that his investigations showed that, "contrary to the belief of many economists, a lighthouse can be provided by private enterprise." This he surely did not do, if by "private enterprise" one means a system of conventional property rights to exclude others from lighthouse properties combined with contracts between lighthouse owners and ships (Van Zandt 1993). If this had been the full extent of the rights of private lighthouse owners, they would have had no practical way of excluding noncontracting ships from benefiting from the information supplied by lighthouse beacons. Free riding would likely be rampant, and private lighthouses would likely go out of business.

Private entities were able to survive in the lighthouse business only because they were given an additional property right by the government: the right to exclude ships from British ports unless the ships paid lighthouse tolls to customs officers, who in turn passed on a portion of the tolls to the operators of lighthouses (Van Zandt 1993, pp. 54-57, 64-69; Bertrand 2006, pp. 396-97). In other words, lighthouse owners were given a separate and distinct property right to exclude vessels stopping at British ports from using the information supplied by the lighthouse without paying a fee. This separate right, analogous to an intellectual property right, is what made the provision of lighthouse services by private entities possible. ${ }^{7}$

What are we to make of the fact that Coase misidentified the relevant property right that made the provision of lighthouse services by private entities possible? This does not necessarily prove that he continued to think of property as a bundle of use rights. Nevertheless, there is, again, circumstantial evidence supporting such an inference. At one point, Coase (1974, p. 375) makes the following remarkable claim about the provision of lighthouse services by private enterprise: " $\mathrm{t}]$ he role of the government was limited to the establishment and enforcement of property rights in the lighthouse. The charges were collected at the ports by agents for the lighthouses. The problem of enforcement was no different for them than for other suppliers of goods and services to the shipowner. The property rights were unusual only in that they stipulated the price that could be charged." This passage makes sense only if Coase believed that the "property

\footnotetext{
${ }^{7}$ A lighthouse owner also needed the Crown's authorization to have the right to enforce the payment of light dues (Bertrand 2006, p. 397).
} 
rights in the lighthouse" could be expanded by the government to include the right to receive a portion of the tolls collected by customs officers from ships using nearby ports. In other words, the bundle of rights associated with owning a tower with a light on top can be modified by the state by adding the right to receive a stream of revenues collected by the government from third parties.

This is, at a minimum, an unconventional way of describing property rights. We do not ordinarily say that the property right of homeowners includes the right to deduct mortgage interest payments from income taxes that the homeowner may owe the government, or that the property right of grocers in foodstuffs includes the right to redeem food stamps collected from patrons in exchange for those foodstuffs. One can, of course, adopt this locution if one embraces the bundle-of-rights conception of property. However, one would not ordinarily speak of property rights as including the prospect of side payments from the government, based on understandings that vary widely with the circumstances of each individual owner.

Notice, in this respect, that the specific deal offered by the government to each private lighthouse operator was highly idiosyncratic-for example, different tolls were charged in different ports for different types of ships, the length of the agreement between the lighthouse operator and the government varied from lighthouse to lighthouse, and so forth. If all these variations are included in the concept of property, then property rights must be envisioned as a complex of in personam rights prescribed by the state, not standardized rights imposing duties of noninterference on all actors. We would conclude, therefore, that the article "The Lighthouse in Economics" reflects, at least implicitly, a continuation of Coase's commitment to the bundle-of-rights picture of property.

A third piece of evidence suggesting that Coase never relinquished the bundleof-rights picture of property is a book (Coase 1988) reproducing his leading articles, including "The Problem of Social Cost" and "The Lighthouse in Economics." The book includes an introduction in which Coase set forth his understanding of the linkages between these articles. In explaining the connection between the 1959 and 1960 articles, he returned once again to the nature of property rights. After reiterating his proposal to allocate rights to use the radio spectrum by market exchange, Coase (1988, pp. 11-12, emphasis added) continued as follows:

I went on to discuss what rights would be acquired by the successful bidder, a question which economists, thinking as they do of factors of production as physical units (tons of fertilizer, acres of land, etc.), usually take for granted. Lawyers, however, habitually think of what is bought and sold as consisting of a bundle of rights. It is easy to see why I was led to adopt the same approach in dealing with the radio frequency spectrum, since it is difficult to treat the use of the right to emit electrical radiations solely in physical terms, particularly since what can be achieved by emitting electrical radiations on a given frequency depends crucially on what use of this and adjacent frequencies is being made by others. It is impossible to think concretely about what would be paid for the use of 
a particular frequency unless there has been some specification of the rights possessed by all the people who use this and adjacent frequencies or who might use them. . . .

There is no difficulty in employing the same approach which I found useful in discussing the allocation of the radio frequency spectrum for the analysis of problems which economists are more accustomed to handle. Someone having the right to build a factory on a piece of land (and wishing to exercise that right) would normally also secure the right to prevent someone else from, say, planting wheat on it; and if the operation of the factory created noise or led to the emission of smoke, the factory-owner would wish to have the right to do this. The factory-owner would chose to use a particular site and create noise and emit smoke because this would produce a higher net income than alternative sites or modes of operation. Exercise of these rights would, of course, deny the use of the land to agriculturalists and clean air to others. . . .

What this approach makes clear is that there is no difference, analytically, between rights such as those to determine how a piece of land should be used and those, for example, which enable someone in a given location to emit smoke.

Here we find Coase explicitly endorsing the bundle-of-rights conception and explicitly extending it from property rights in unusual resources, such as the radio spectrum, to conventional rights in land. Some of his language even goes so far as to suggest that there is no standard default bundle of land ownership but merely ad hoc collections of use rights, which are assembled one tract at a time. Thus, for example, he says that someone buying land for a factory "would normally also secure the right to prevent someone else from, say, planting wheat on it" (Coase 1988, p. 11). We seriously doubt that Coase entertained the notion that property rights are purely ad hoc assemblages of rights and privileges, like ingredients at a Mongolian barbecue restaurant. More likely, he should be understood as saying that the common law has defined certain default packages of use rights associated with land, which in the ordinary case would include the right to build a factory and to exclude someone else who wanted to use the land to plant wheat. However, he clearly conceived of each use right as contingent on the evolved state of the law and as freely exchangeable through contracting. This is the bundle-of-rights picture of property.

\section{Property as an In Rem Right}

As should be obvious from the many examples of influence that we cited in Section 2, Coase's picture of property did not inhibit rapid progress in the development of the economic analysis of property. Nevertheless, we will argue that Coase's picture of property had a distorting influence and that, in certain respects, it may have impeded intellectual progress in developing our understanding of the institution of property.

Notwithstanding the impressive payoffs from Coase's work, the list-of-uses conception of property implicit in his articles also had its costs. The picture of property as an ever-mutable bundle of rights has long blinded economic scholars to the in rem features of property, which means that they have ignored or 
downplayed certain dimensions of any system of property rights. We will mention three key implications that flow from the in rem understanding of property and that were long overlooked in the wake of Coase.

First, the bundle-of-rights picture fails to capture the centrality of exclusion rights to the institution of property. Because the owner has the right to exclude the world, the owner assumes the role of gatekeeper or manager of the asset (Penner 1997, pp. 29-30, 71; Merrill 1998, p. 739; Smith 2005, pp. 78-79). This means, among other things, that the owner has a powerful incentive to invest in and develop the asset, because the owner will capture the benefit of these actions as the residual claimant. ${ }^{8}$ Thus, exclusion accounts for the dynamic efficiency of property, as opposed to the allocational efficiency that comes from the free exchange of rights. Under the bundle-of-rights picture, in contrast, the exclusion right fades into the background as part of the general bundle of sticks, no more important than the right to inherit or the right to use the asset for particular purposes.

Second, the bundle-of-rights picture fails to highlight the enormous information cost constraints associated with any system of in rem rights. This is most pronounced if we think about the situation of potential violators of in rem rights (Merrill and Smith 2000, p. 8; Smith 2003, pp. 1146-47; Merrill and Smith 2007a, pp. 1850, 1854). If everyday property_rights to land and chattels_entails rights to exclude all the world from some thing, this sets up a potentially severe information cost problem for potential violators of these rights. The costs of communicating information about rights and duties in a world that consists solely of in personam or A-to-B rights would be significant. Each person would have to be aware of and comprehend all the obligations that they had personally undertaken or that had been imposed upon them. The costs of communicating information about in rem rights and duties that apply to everyone are potentially much greater. If every property right was described by a customizable list of permitted uses_-as Coase imagined with respect to stones from different quarries or individual British lighthouses - and if these rights had to be understood and respected by all the world, the resulting information costs would be staggering.

This in turn suggests that the messages about everyday property must be very simple_-messages such as "keep off" or "don't touch" — couched in concepts readily comprehensible to remote people with little special legal or asset-specific information. ${ }^{9}$ It also suggests that the signaling mechanisms for delineating the boundaries of property must be easily observable and comprehensible, things such

\footnotetext{
${ }^{8}$ For example, Barzel (1997, pp. 3-4) introduces his theory in which the notion of rights "is closely related to that of residual claimancy" and the notion of property rights "is closely related to that of transaction costs," because the residual claimant enjoys attributes of assets that cannot be captured in contracts due to transaction costs. Alchian and Demsetz (1972) describe the residual claimant as one with incentives to reduce shirking and with the most significant management potential.

${ }^{9}$ For example, Ellickson (1993, pp. 1328-29) notes that fences and other boundary markers are more readily apparent to outsiders than a group's internal work rules. Merrill and Smith (2001b, pp. 388-94) discuss the simplicity of messages about property to dutyholders in the context of social norms and causation of harm. See also Rose (1991, pp. 18, 20) and Smith (2003, pp. 1116-17).
} 
as fences and hedge rows that mark the edges of land ownership (Rose 1994, pp. 267-304; Smith 2003, pp. 1115-25, 1174-75; Ellickson 2011). The bundle-of-rights conception obscures the need for communication to potential violators on a mass scale, and it thus suggests that property rights are much more malleable than we observe them to be in actual practice.

Even if we confine ourselves to potential transactors in property rights- the more common Coasean perspective-the in rem nature of property also underscores the need to communicate with a large potential audience (Merrill and Smith 2000, pp. 24-42; Smith 2003, pp. 1139-67). The types of transactions emphasized by Coase-agreements between two neighbors to modify entitlements more efficiently to manage spillover effects-are relatively rare. Much more common are outright purchases, leases, licenses, and lending of all stripes and varieties. For the potential parties to these transactions to make judgments about who owns what, it is necessary that the available forms of property and conventions about the respective priorities of different lenders be significantly standardized. Standardization to the degree necessary for random potential violators is not necessary. However, free customization of interests between A and $B$ would be unacceptable, because this would create an informational externality for other potential transactors. The added informational burden would affect not only future transactors in the property transferred from $\mathrm{A}$ to $\mathrm{B}$ but all potential transactors who would have to be on the lookout for deviant forms of property or security interests in unrelated transactions (Merrill and Smith 2000, pp. 26-27, 31-33; Smith 2011, pp. 20-34).

One might think that land records would obviate the need for standardization. ${ }^{10}$ However, cross-country empirical work on land records suggests that land records and standardization are, to some extent, complements: more definitive land records that guarantee title tend to have a stricter numerus clausus, allowing fewer property forms, apparently because the registrar of titles stands in for the public as the audience for rights and cannot be expected to pass judgment on all sorts of idiosyncratic rights (Arruñada 2003, pp. 1416-20). By contrast, the bundle-of-rights picture emphasizes the plasticity and variety of packages of property rights. Again, the bundle-of-rights picture of property obscures the need for this degree of standardization of rights.

Third, the in rem nature of property rights renders implausible one of the principal claims of Coase's 1960 article, which is that the problem of social cost is reciprocal in nature, and thus it is not useful to speak of one party to an externality as being the cause of any problem of incompatible demands on resources (Coase 1960, pp. 8-15, 37). Lawyers have always had trouble accepting

\footnotetext{
${ }^{10}$ For example, Conard (1942, pp. 131-33) and Epstein (1982) argue that the enforcement of easements should not be objectionable on grounds of novelty as long as there is notice. Hansmannn and Kraakman (2002, pp. S416-S417) fall into this trap when their assertion that recording removes reasons for standardization leads them to claim-erroneously-that the numerus clausus has no basis in common law.
} 
this claim, offering counterexamples such as A's fist striking B's nose. ${ }^{11}$ The idea of reciprocal causation is not, strictly speaking, entailed by the bundle-of-rights picture of property. One could theoretically retain the idea of asymmetric causation with respect to (at least some) of the uses included within the bundle. Once we recognize the in rem nature of rights in property and bodily integrity, however, the idea of reciprocal causation is not just a contingent feature of the legally sanctioned bundle-it becomes utterly implausible.

Rights good against the world have a built-in asymmetry. We could imagine solving questions of resource use pairwise between everyone: A versus B, A versus $\mathrm{C}, \mathrm{B}$ versus $\mathrm{C}$, and so on. However, many of the various combinations would never be used, making A versus everyone else a reasonable first approximation. A versus everyone else is asymmetric: the class of everyone else is almost inevitably much larger and more indefinite than the class that includes just A. Consider the rights to use a car. If A has the right and can exclude all others, then it is clear that anyone else who wants to use the car must strike a deal with A. The costs of transactions under such an arrangement are manageable. However, if all the world has the right to use the car, then if A wishes to use the car for any period, A will have to strike a deal with all the world (Holderness 1985). The costs of entering into transactions under this allocation of rights are extremely large-indeed, they are potentially infinite. If we say that the difference between these two arrangements disappears if we assume zero transaction costs, then this significantly undermines the heuristic value of the assumption of zero transaction costs, since the transaction costs differ enormously depending on the assignment of rights.

Is the basic package of rights associated with the in rem picture of property a mystification or legal irrelevancy, like the color of the judge's eyes (Coase 1960, p. 29)? Our answer is no, and that answer relates back to the Coase theorem, but in a more thoroughgoing way than was envisioned by Coase. It is time to turn the Coasean spotlight back on the picture of property as a bundle of sticks.

\section{Property and the Coase Corollary}

Not only was Coase's picture of property wholly tangential to the major contributions that have flowed from his groundbreaking work, it was inconsistent with the main tenor of his work. Although Coase aimed to show the influence of the legal system on the workings of the economic system, his framework, as we have seen, has been immensely fruitful as a tool of institutional analysis. In this spirit, we apply Coase's framework to the notion of property itself-an important legal and economic institution if ever there was one.

Coase did not present his work in "The Problem of Social Cost" as a theorem, but starting with George Stigler in the mid 1960s, Coase’s argument that, in a

\footnotetext{
${ }^{11}$ For example, Gjerdingen (1983, pp. 724-25) ascribes this resistance to psychological differences between economic and common-law conceptions of causation.
} 
world with zero transaction costs, people will always reach the wealth-maximizing result through contracting (or through other equally costless institutional responses) has come to be known as the "Coase theorem."12 Coase much later summarized his article as "show[ing] . . . that, in the absence of transaction costs, it does not matter what the law is, since people can always negotiate without cost to acquire, subdivide, and combine rights whenever this would increase the value of production" (Coase 1988, p. 14). ${ }^{13}$ The point of the exercise was to show the importance of transaction costs in the real world. Far from endorsing a view of the world based on an assumption of zero transaction costs, Coase's aim was nearly the opposite. As Coase (1988, p. 174) wrote, "The world of zero transaction costs has often been described as a Coasean world. Nothing could be further from the truth. It is the world of modern economic theory, one which I was hoping to persuade economists to leave." ${ }^{14}$ By pointing out the strangeness of the proposition that the legal position is irrelevant to the pattern of production, Coase was highlighting the importance of transaction costs to institutional design.

The relevant institutions go far beyond the thin question of who, as between a pair of actors, will be liable for an activity involving a resource conflict. ${ }^{15}$ One critical institution is the firm. Firms are economic institutions, which, because of Coase's work, we now see as explained by transaction costs. Coase himself saw that what came to be known as the Coase theorem is closely related to his earlier work (Coase 1937) on the theory of the firm. In that article, Coase showed that the boundary of the firm can only be explained by the relative costs of conducting transactions within the firm (by fiat) and outside the firm in the market (by market contracting). In other words, "in the absence of transaction costs, there is no basis for the existence of firms" (Coase 1988, p. 14).

Another critical institution is property itself. We have property and endow it with a basic architecture of exclusion rules supplemented by rules and standards governing proper use, precisely because of transaction costs. The term "transaction costs" in a sense replicates some of the hidden bias toward contracts and away from property in Coase's seminal work. The term "transaction costs" can be taken narrowly or broadly. ${ }^{16}$ For institutional analysis or, in other words,

\footnotetext{
${ }^{12}$ Stigler (1966, p. 113) defined the Coase theorem as a proposition that "under perfect competition private and social costs will be equal."

${ }^{13}$ For information on how Coase assumes away strategic behavior, see, for example, Cooter (1982), who emphasizes strategic behavior by comparing the Coase theorem and the Hobbes theorem. For information on abstraction away from issues like the effects of wealth on consumers in Coase's analysis, see Demsetz (1972) and Schwab (1989, pp. 1178-84). Coase also offers his on view on these issues (Coase 1988, pp. 170-74).

${ }^{14}$ For discussion of how the Coase theorem has been widely misunderstood, see Farber (1997) and McCloskey (1998).

${ }^{15}$ On the bilateral approach to liability, see, for example, Calabresi (1970, pp. 135-73, 261-63), Calabresi and Hirschoff (1972, p. 1060), and Demsetz (1972, pp. 27-28).

${ }^{16}$ Allen (1991) argues that transaction costs are better defined as the costs of establishing property rights, in the economist's sense of a de facto ability to derive utility from an action, rather than narrowly as the costs of exchange.
} 
transaction cost economics, the frictions captured by the term "transaction costs" go beyond the costs of exchange in the sense of a quid pro quo. Coase was preoccupied with the costs of exchange of rights and treated transaction costs as the resources that must be expended "to discover who it is that one wishes to deal with . . . and on what terms, to conduct negotiations leading up to a bargain, to draw up a contract, to undertake the inspection needed to make sure that the terms of the contract are being observed, and so on" (Coase 1960, p. 15). However, transaction costs also include other costs of institutions. Most relevant for us are all the resources that must be expended to determine what is being exchanged: the costs of delineating, understanding, and enforcing rights to particular resources. Some or all of these costs have variously gone under the headings of entitlement determination costs (Merrill 1985, pp. 20-26), information costs (Stigler 1961; Alchian and Demsetz 1972; Dahlman 1979, p. 148), measurement costs (Barzel 1982, p. 1997), and institution costs (Cheung 1998, p. 515; Smith 2008, p. 447). Although it is true that in analyzing particular institutions, it is necessary to be clear about which transaction costs are actually in play, ${ }^{17}$ we will employ the Coasean term "transaction costs" to explore the implications of Coase's work, albeit with the understanding that transaction costs include these other costs of a system of property rights and alternative institutional arrangements.

Once we recognize that property is an institution shaped by positive transaction costs in this broad sense, we come to what we dub the Coase corollary:

Coase Corollary. In a world of zero transaction costs, wealth maximization will occur regardless of the nature and scope of property rights.

The intuition behind the Coase corollary is straightforward and directly parallels the intuition behind the Coase theorem. In a world of zero transaction costs, it would not matter whether property rights are broad or narrow, clear or ambiguous, or in rem or in personam. For example, it would not matter whether the boundary of land is marked by precise lines or whether the boundary is fuzzy and use rights are determined through case-by-case balancing of the needs of rival claimants. Nor would it matter if property rights were standardized (as in the numerus clausus) or if idiosyncratic rights were allowed to proliferate. Either way, as long as transaction costs are zero, the respective rights of all affected parties will be instantly and costlessly ascertained. Similarly, it does not matter if property can be held in only one form—say, the fee simple absoluteor if each item of property has its own unique set of attributes. Either way, as long as transaction costs are zero, all affected parties can either instantly and costlessly generate new forms (if there are not enough) or can instantly and costlessly communicate about and understand the forms that do exist (if there are infinitely many).

\footnotetext{
${ }^{17}$ Schlag (1989, pp. 1674-76) notes the widely divergent definitions of transaction costs and warns of dangers of tautology in broad definitions for the Coase theorem.
} 
Indeed, in a world with zero transaction costs, it would not matter whether we had anything like property law at all. ${ }^{18}$ We could, instead, just as easily regard property as being the solution of all pairwise conflicts between members of society with respect to each potential resource conflict-the most extreme bundle-of-rights picture of property imaginable. The delineation, understanding, and enforcement of these highly atomized rights would cost no more than a system in which rights were understood as having a standardized form and as imposing duties of respect on all persons. Also, as we saw earlier, the highly atomized list-of-uses approach to property is Coase's picture of property (Merrill and Smith 2001b, p. 385).

However, as with the Coase theorem, the lesson of the Coase corollary is to subject the notion of property to comparative institutional analysis, and it is here that we argue that the extreme bundle-of-rights picture of property comes up far short. Indeed, this hyper-Realist picture is plausible (much less realistic) only in a world of zero transaction costs: the world Coase tried to persuade economists to leave.

In our world of positive transaction costs, the lumpy, in rem property rights are no accident precisely because they save on delineation, understanding, and enforcement costs. Furthermore, in our world with positive transaction costs, one should expect to find a significant degree of standardization of rights, precisely because this would save on delineation, understanding, and enforcement costs. This is not to say that rights will be maximally standardized. There is an inevitable trade-off between the reduction of information costs through standardization of rights and the need for flexibility in offering a variety of options in terms of how entitlements are delineated and defined. ${ }^{19}$ Still, the exploration of a world with zero transaction costs makes clear what we would otherwise miss because it is so obvious: that property rights assume the form they do in significant part to conserve on transaction costs. Nothing could be more Coasean. Despite not being Coase's picture of property, this more realistic picture is the result of applying the true Coase theorem back on the notion of property itself.

Such an exercise is no mere theoretical curiosity. The Coase corollary sheds light on some of the very questions that Coase addressed in his articles. Take the problem of spillovers that Coase illustrated with nuisance cases (Coase 1960, pp. 8-10). When deciding a nuisance case, we are not writing on a blank slate and are not really asking judges to engage in a cost-benefit analysis. Coase may be right that the ultimate question is who gets to do what and that this determines the value of production. However, because of transaction costs, we delegate to owners a range of sovereign authority over their property, with a presumptive right to repel invasions through some combination of self-help and litigation

\footnotetext{
${ }^{18}$ Cheung (1998, pp. 518-20) recognized that a thoroughgoing version of the zero-transactioncost assumption would remove the need for property rights at all. Coase (1988, pp. 14-15) has agreed in principle with this observation.

${ }^{19}$ As Merrill and Smith (2000, p. 38) note, the need is for optimal, rather than maximal, standardization of property forms.
} 
(or its threat). This view of nuisance is more realistic than Coase's view, because a truly universal ex post balancing test for resource conflict would be prohibitively costly.

This is not to say that owners always win. For one thing, the sovereignty afforded owners through the exclusion strategy is only a starting point. The presumption that owners can veto invasions sometimes gives way-for example, to the need for airplane overflights and the need for antidiscrimination law (Merrill and Smith 2007b, pp. 9-15, 456-80; Smith 2009b). Sometimes, owners will not be able to shut down activities emitting sound or odors-for example, if the locality is characterized by such activities (Bone 1986, pp. 1159-60 n.126). In other situations, owners may be relegated to a remedy of damages rather than an injunction (Boomer v. Atlantic Cement Company, 257 N.E.2d 870 [N.Y. 1970]). These questions, too, all turn in part on considerations of transaction costs: both the entitlement determination and processing costs and the (narrower) transaction costs associated with potential exchanges. ${ }^{20}$ However, analyzing these important use conflicts from a transaction cost point of view should not obscure the important starting point: for transaction cost reasons, we start with sovereign owners exercising the right to exclude over clearly delineated things, and we use this starting point to resolve a wide range of resource conflicts.

The Coase corollary also calls into question aspects of the Coase-inspired analysis of property rules and liability rules set forth by Calabresi and Melamed (1972). As one of us has written (Smith 2005, pp. 70-76), Calabresi and Melamed's assumption of a thin notion of entitlement is essential to the symmetry result in their framework. However, the thin notion of entitlement, drawn as it is from Coase and the world of zero transaction costs, breaks down in the face of the need for significant standardization of rights in our positive-transactioncost world (Schroeder 1999, pp. 433-35; Smith 2004, pp. 1019-21; Smith 2005, pp. 72-76; Michelman 2005, pp. 147-52; Fennell 2007, p. 1404 n.10). If A is sending emissions from A's land to B's land, we are not in a position to be as agnostic about the direction of causation as we might be in a world of zero transaction costs. Even the law of nuisance takes the right to be free from a wide range of invasions into the owner's column of space as the starting point. ${ }^{21}$ This principle of owner entitlement saves on delineation costs, as opposed to the thin set of sticks in a giant list of use conflicts.

Therefore, if, under rule 1 , the resident has the entitlement to be free from pollution protected by a property rule (injunction) and, under rule 2 , has the entitlement protected by a liability rule (meaning that the polluter can pollute and

\footnotetext{
${ }^{20}$ The mainstream position in law and economics endorses the shift to damages in large-numbers situations, to prevent holdouts (see, for example, Calabresi and Melamed 1972, pp. 1106-10; Cooter and Ulen 1988, pp. 170-80; Cooter 1985, pp. 26-27; Polinsky 1979, p. 4; Polinsky 1980, p. 1076; Posner 1998, pp. 16, 68-71, 79-81). For skepticism about this approach, see, for example, Farber (1988, pp. 7-8) and Smith (2004, pp. 1037-45).

${ }^{21}$ For recent analyses from a variety of perspectives that try to bring the more traditional invasionbased test back to the fore, see, for example, Epstein (1979a, pp. 53-65), Penner (1993, pp. 14-25), Smith (2004, pp. 992-96), and Claeys (2010, pp. 1409-13).
} 
pay officially determined damages), the question of what it would mean to flip things around arises. Calabresi and Melamed believe that, in accord with Coasean causal symmetry, the polluter could be given the entitlement, and then we face a parallel choice between protecting that entitlement with a property rule (rule 3 ) or a liability rule (rule 4). What they envision is a situation in which the factory owner can pollute but the resident cannot get a remedy, thus forcing the resident to pay the polluter if the pollution is to stop (Calabresi and Melamed 1972, p. 1116). However, this is not truly parallel or symmetrical to the rule 1 situation (Smith 2005, pp. 74-76). If it were, then the factory owner would have a right to pollute. If the resident puts up a giant fan and blows the pollution back, can the polluter get an injunction? If not, there is no right to pollute but rather an ability to get away with it. As part of the default package of property rights, no one has the right to pollute in this robust sense (entailing a right to enjoin fans). The factory owner could have a right to pollute if it has an easement (by grant or prescription), which might give it the right to enjoin fans, but this is an add-on to the baseline default package of rights in land. When it comes to the resource conflict, there is an entitlement structure in place, and it breaks the symmetry on which Calabresi and Melamed are relying.

Much the same can be said about rule 4 (Smith 2004, pp. 1007-21; Smith 2005, pp. 74-75). Although in some situations of undue hardship there is a rationale to soften the remedy from injunctions to damages (rule 1 to rule 2), there is no parallel rationale from moving from rule 3 , which exists only in the specific context of an easement, to rule 4 , by allowing residents to shut down pollution on paying damages. This may be one reason why rule 4 is almost unheard of in the nuisance context. ${ }^{22}$ Again, the baselines that get in the way of both the Realists' (and Coase's) bundle-of-sticks entitlements and Coasean causal symmetry stem from the institutional analysis called for by the Coase corollary: we do not proceed in the agnostic bundle-of-sticks fashion, because of transaction costs.

Relatedly, the need for significant standardization of rights as a response to positive transaction costs also helps explain why Coase's view of causation as reciprocal—what we have called Coasean causal agnosticism-does not carry over from the world with zero transaction costs into our world of positive transaction costs (Merrill and Smith 2001b, pp. 391-94). Once we have a system of in rem property rights in place, it makes no sense to be causally agnostic, for transaction cost reasons. If A's action causes particles or waves to travel over the boundary and into B's column of space, the presumptive answer is that A is harming B and

\footnotetext{
${ }^{22}$ The one heavily rehearsed case is Spur Industries, Incorporated v. Del E. Webb Development Company, 494 P.2d 700, 708 (Ariz. 1972) (en banc). Another reason for the rarity of rule 4 is that it requires collecting potential plaintiffs to avoid free rider problems, as for example in a class action. In Spur, the developer, who made the decision to build close to the feedlot, was the one suing rather than the residents, but to the extent that this matters to courts, developers will try to avoid being the plaintiff in the future.
} 
not vice versa. Conventional in rem property rights are not the only source of baseline entitlements, ${ }^{23}$ but they are a wholesale source of them.

This lack of symmetry is also at the root of the gravitational pull that the ad coelum rule exerts in many contexts. ${ }^{24}$ Even in situations governed by social norms, we find that norms based on the ad coelum approach are more widespread than a comparison of values of the conflicting activities would warrant. Thus, in the prototypical Coasean example of wandering cattle and trampled crops (Coase 1960, pp. 2-8), cattle have to be significantly more important than crops to flip from fencing in (rancher liability) to fencing out (rancher nonliability) (Merrill and Smith 2001b, pp. 390-91). Even norms tend to track the ad coelum rule, with fencing-in norms being more widespread than one would expect on an approach of choosing the more valuable activity for the immediate area. ${ }^{25}$

Likewise, general norms of possession seem to form powerful defaults: in the law of possession, certain control over a thing is a default requirement unless an important resource clearly cries out for different treatment. Ellickson (1989) found a pattern of nineteenth-century whaling norms that can be seen as conforming to a simple general rule, with an exception for special important situations. Under the fast-fish-loose-fish rule, the first harpooner gets the whole whale as long as the whale is attached to his boat. This rule, which accords with general notions of certain control in first possession, applied to right whales, which are relatively slow moving, and to whales generally, with some major exceptions. Under the iron-holds-the-whale or first-iron rule, the first harpooner would get exclusive rights to the whale as long as he was in fresh pursuit, which requires more judgment. The first-iron rule tended to be adopted where the very valuable but very dangerous sperm whales were predominant. For finback whales, which sink and rise to the surface, the custom was marking with a bomb lance and giving a small fee to finders who were obligated to report beached marked finbacks (Ghen v. Rich, 8 F. 159, 159-60 [D. Mass. 1881]). Ellickson (1989, pp. 88-94) argues that these norms confirm his hypothesis that close-knit groups will devise efficient norms among themselves (but with the possibility of outgroup externalities, such as overexploitation). But note that the general norm of first possession based on certain control is the default rule for whales (Smith 2003, pp. 1119-22). Simple baselines matter, and they matter because of infor-

\footnotetext{
${ }^{23}$ Another source is custom. For a discussion of custom as a baseline, including the famous cedarapple rust situation of Miller v. Schoene (276 U.S. 272 [1928]), see Fischel (2007, pp. 149-51) and Smith (2009a pp. 38-41).

${ }^{24}$ For a discussion of some of those contexts, see Merrill and Smith (2001b, pp. 388-91). The full statement of the maxim is cujus est solum, ejus est usque ad coelum et ad inferos (whoever owns the soil owns also to the sky and to the depths). The maxim is routinely followed in resolving issues about ownership of air rights, building encroachments, overhanging tree limbs, mineral rights, and so forth, and is subject to certain limited exceptions for airplane overflights, for example. See Brown v. United States, 73 F.3d 1100, 1103 (Fed. Cir. 1996); see also Merrill (1985, pp. 35-36).

${ }^{25}$ Ellickson (1991, pp. 52-53, 72-76) shows the widespread use of an informal norm of animalowner responsibility, regardless of the legal regime, and Merrill and Smith (2001b, pp. 388-91) relate this widespread norm of fencing in to the transaction costs of basic package of entitlements.
} 
mation costs, which are an important species of transaction costs. Again, it is the Coase corollary in action.

Finally, the distinction between in rem and in personam rights, which lies at the heart of the traditional property/contract distinction, is likewise a product of transaction costs. In a world of zero transaction costs, one could redescribe in rem rights against all the world in terms of a congeries of in personam rights, as Hohfeld imagined. ${ }^{26}$ That is, one could cash out the idea of A having a right against all the world as being equivalent to $\mathrm{A}$ having a right against $\mathrm{B}$, a right against $\mathrm{C}$, a right against $\mathrm{D}$, and so on. This equivalence would hold, however, only in the world of the Coase corollary. In the real world of positive transaction costs, it is prohibitively costly to list everyone in the world to describe all the persons who are bound by A's having a right in rem. Likewise, contracting pairwise would be unfeasibly costly. Instead, it is necessary to solve many problems wholesale through in rem rights-including core property rights-which impose automatic duties of noninterference on all persons who may or may not encounter the owned property, whoever they may be, and whether or not they have any conception of who the owner might be. In our world of positive transaction costs, in rem duties are not and cannot be equivalent to an enormously long list of in personam duties.

By having the right to exclude from some thing, A is given sovereignty over a range of largely unspecified uses that must be respected by a largely unspecified set of duty holders. We do not deny that many aspects of property differ according to conditions of time, place, and culture. It is no accident, however, that property is defined in terms of things as a starting point, uses are protected indirectly by exclusion rights, and in rem rights are employed on a widespread basis; these features of property receive a transaction cost explanation. Establishing starting points or baselines in property is not a trivial problem, and for transaction cost reasons could not be replicated by contract. Establishing such baselines is thus, to borrow a phrase, an essential role of the law of property. ${ }^{27}$ The need for the baseline entitlements to be largely unspecified is a direct result of the Coase corollary. Positive transaction costs in our world make it advantageous to economize on the costs of delineating, understanding, and enforcing entitlements. Hence, the preference for the traditional notion of property as opposed to the bundle of rights. Rather than Coase's atomized picture of property, our positivetransaction-cost world exhibits the highly standardized, truly Coasean property familiar from the law of property.

\footnotetext{
${ }^{26}$ Wesley Hohfeld famously analyzed in rem rights as collections of in personam rights, as part of an atomizing scheme of legal relations that was quite inspiring to the Legal Realists. See Hohfeld (1917) and Merrill and Smith (2001a, pp. 780-89). Kocourek (1920, p. 322) noted the influence in both civil-law and common-law traditions of Austin's civilian-style definition of in rem rights as "'rights residing in persons and availing against other persons generally" and related formulations including the familiar phrase "against the world."

${ }^{27}$ Hansmann and Kraakman (2000, pp. 393-94) argue that affirmative asset partitioning, protecting the firm's assets from the owner's creditors, could not be replicated by contract and is therefore the essential role of organizational law.
} 


\section{Conclusion}

In this essay, we have sought to make Coasean property more Coeasean. We started by showing what picture of property Coase subscribed to in his groundbreaking work. Coase's picture of property was an extreme version of the Legal Realist bundle of rights. This highly atomized bundle-of-rights picture treats property as a collection of governmentally resolved pairwise use conflicts among members of society, with a background assumption of symmetry of causation and entitlement allocation. The bundle-of-rights picture has carried over into Coase-inspired work in law and economics and the New Institutional Economics.

Coase's picture of property was wholly tangential to the major contributions that have flowed from his seminal articles. The importance of transaction costs in the design of legal institutions, the importance of contracting as a device for internalizing externalities, and the need to engage in comparative institutional analysis in proposing solutions to problems of social cost-all these transformative insights could have been made and their value fully realized without accepting the bundle-of-rights picture of property.

We have gone further, and we have also argued that applying Coasean economic-institutional analysis to the institution of property itself reveals a Coasean rationale for traditional notions of property as an in rem right to a thing. To this end, we introduced the Coase corollary, which states that, in a world of zero transaction costs, the nature and scope of property are irrelevant to the value of production. As with the Coase theorem, from which it directly follows, the point of the Coase corollary is that, in our world of positive transaction costs, the nature and scope of property do matter to the allocation of resources and the value of production. The truly Coasean approach is to engage in comparative institutional analysis of the notion of property itself. Here baselines matter, and because of positive transaction costs -in particular, the costs of delineating, understanding, and enforcing rights_entitlements are built using an in rem exclusion strategy to define things and take care of many conflicts wholesale, with refinements governing uses through institutions like zoning, nuisance, contracts, and norms. Traditional property as defined in law turns out to be quite Coasean after all.

\section{References}

Ackerman, Bruce A. 1977. Private Property and the Constitution. New Haven, Conn.: Yale University Press.

$\rightarrow$ Alchian, Armen A., and Harold Demsetz. 1972. Production, Information Costs, and Economic Organization. American Economic Review 62:777-95.

$\rightarrow$ Allen, Douglas W. 1991. What Are Transaction Costs? Research in Law and Economics 14: $1-18$.

Alston, L. J. 2008. New Institutional Economics. Pp. 32-39 in vol. 6 of The New Palgrave Dictionary of Economics, edited by Steven N. Durlauf and Lawrence E. Blume. $2 \mathrm{~d}$ ed. Basingstoke and New York: Palgrave Macmillan. 
Arruñada, Benito. 2003. Property Enforcement as Organized Consent. Journal of Law, Economics, and Organization 19:401-44.

$\rightarrow$ Barzel, Yoram. 1982. Measurement Cost and the Organization of Markets. Journal of Law and Economics 25:27-48.

- 1997. Economic Analysis of Property Rights. 2d ed. Cambridge and New York: Cambridge University Press.

Bentham, Jeremy. 1945. The Limits of Jurisprudence Defined, edited by Charles Warren Everett. New York: Columbia University Press.

- [1782] 1970. Idea of a Complete Law. Chapter 14 in Of Laws in General, edited by H. L. A. Hart. London: University of London, Athlone Press.

$\rightarrow$ Bertrand, Elodie. 2006. The Coasean Analysis of Lighthouse Financing: Myths and Realities. Cambridge Journal of Economics 30:389-402.

Blackstone, William. [1766] 1979. Commentaries on the Laws of England. Vol. 2. Chicago: University of Chicago Press.

Bone, Robert G. 1986. Normative Theory and Legal Doctrine in American Nuisance Law: 1850 to 1920. Southern California Law Review 59:1101-1226.

Burns, Robert P. 1985. Blackstone's Theory of the "Absolute” Rights of Property. University of Cincinnati Law Review 54:67-86.

Calabresi, Guido. 1970. The Costs of Accidents: A Legal and Economic Analysis. New Haven, Conn.: Yale University Press.

$\rightarrow$ Calabresi, Guido, and Jon T. Hirschoff. 1972. Toward a Test for Strict Liability in Torts. Yale Law Journal 81:1055-85.

$\rightarrow$ Calabresi, Guido, and A. Douglas Melamed. 1972. Property Rules, Liability Rules, and Inalienability: One View of the Cathedral. Harvard Law Review 85:1089-1128.

$\rightarrow$ Cheung, Steven N. S. 1998. The Transaction Costs Paradigm. Economic Inquiry 36:514-21.

Claeys, Eric R. 2010. Jefferson Meets Coase: Land-Use Torts, Law and Economics, and Natural Property Rights. Notre Dame Law Review 85:1379-1446.

Coase, R. H. 1937. The Nature of the Firm. Economica, n.s., 4:386-405.

$\rightarrow$. 1959. The Federal Communications Commission. Journal of Law and Economics 2:1-40.

$\rightarrow \longrightarrow$ 1960. The Problem of Social Cost. Journal of Law and Economics 3:1-44.

$\rightarrow$. 1974. The Lighthouse in Economics. Journal of Law and Economics 17:357-76.

. 1988. The Firm, the Market, and the Law. Chicago: University of Chicago Press.

$\rightarrow$. 1998. Comment on Thomas W. Hazlett: Assigning Property Rights to Radio Spectrum Users: Why Did FCC License Auctions Take 67 Years? Journal of Law and Economics 41:577-80.

Coase, Ronald, William H. Meckling, and Jora Minasian. 1995. Problems of Radio Frequency Allocation. RAND Unrestricted Draft No. DRU-1219-RC, 1995. Santa Monica, Calif.: RAND Corporation. http://www.rand.org/pubs/drafts/2008/DRU1219.pdf.

$\rightarrow$ Cohen, Felix S. 1935. Transcendental Nonsense and the Functional Approach. Columbia Law Review 35:809-49.

$\rightarrow$ Conard, Alfred F. 1942. Easement Novelties. California Law Review 30:125-50.

$\rightarrow$ Cooter, Robert. 1982. The Cost of Coase. Journal of Legal Studies 11:1-33.

$\rightarrow-$ 1985. Unity in Tort, Contract, and Property: The Model of Precaution. California Law Review 73:1-51.

Cooter, Robert, and Thomas Ulen. 1988. Law and Economics. Glenview, Ill.: Scott Foresman. 
$\rightarrow$ Corbin, Arthur Linton. 1922. Taxation of Seats on the Stock Exchange. Yale Law Journal 31:429-31.

$\rightarrow$ Dahlman, Carl J. 1979. The Problem of Externality. Journal of Law and Economics 22: $141-62$.

$\rightarrow$ Demsetz, Harold. 1967. Toward a Theory of Property Rights. American Economic Review 57(2):347-59.

$\rightarrow \longrightarrow$. 1972. When Does the Rule of Liability Matter? Journal of Legal Studies 1:13-28.

Eggertsson, Thráinn. 1990. Economic Behavior and Institutions. Cambridge and New York: Cambridge University Press.

$\rightarrow$ Ellickson, Robert C. 1973. Alternatives to Zoning: Covenants, Nuisance Rules, and Fines as Land Use Controls. University of Chicago Law Review 40:681-781.

$\rightarrow$. 1989. A Hypothesis of Wealth-Maximizing Norms: Evidence from the Whaling Industry. Journal of Law, Economics, and Organization 5:83-97.

— 1991. Order without Law: How Neighbors Settle Disputes. Cambridge, Mass.: Harvard University Press.

$\rightarrow$. 1993. Property in Land. Yale Law Journal 102:1315-1400.

- 2011. The Inevitable Trend toward Universally Recognized Signals of Property

Claims: An Essay for Carol Rose. William and Mary Bill of Rights Journal 19:1015-32.

$\rightarrow$ Epstein, Richard A. 1979a. Nuisance Law: Corrective Justice and Its Utilitarian Constraints. Journal of Legal Studies 8:49-102.

- 1979b. Possession as the Root of Title. Georgia Law Review 13:1221-43.

- 1982. Notice and Freedom of Contract in the Law of Servitudes. Southern California Law Review 55:1353-68.

Farber, Daniel A. 1988. Reassessing Boomer: Justice, Efficiency, and Nuisance Law. Pp. 726 in Property Law and Legal Education: Essays in Honor of John E. Cribbet, edited by Peter Hay and Michael H. Hoeflich. Urbana: University of Illinois Press.

$\rightarrow$. 1997. Parody Lost/Pragmatism Regained: The Ironic History of the Coase Theorem. Virginia Law Review 83:397-428.

$\rightarrow$ Fennell, Lee Anne. 2007. Property and Half-Torts. Yale Law Journal 116:1400-1471.

Fischel, William A. 2007. The Law and Economics of Cedar-Apple Rust: State Action and Just Compensation in Miller v. Shoene. Review of Law and Economics 3:133-95.

Fried, Barbara H. 1998. The Progressive Assault on Laissez Faire: Robert Hale and the First Law and Economics Movement. Cambridge, Mass.: Harvard University Press.

Gjerdingen, Donald H. 1983. The Coase Theorem and the Psychology of Common-Law Thought. Southern California Law Review 56:711-60.

Grey, Thomas C. 1980. The Disintegration of Property. Pp. 69-85 in NOMOS XXII: Property, edited by J. Roland Pennock and John W. Chapman. New York: New York University Press.

$\rightarrow$ Hansmann, Henry, and Reinier Kraakman. 2000. The Essential Role of Organizational Law. Yale Law Journal 110:387-440.

$\rightarrow-$ 2002. Property, Contract, and Verification: The Numerus Clausus Problem and the Divisibility of Rights. Journal of Legal Studies 31:S373-S420.

$\rightarrow$ Hazlett, Thomas W., David Porter, and Vernon Smith. 2011. Radio Spectrum and the Disruptive Clarity of Ronald Coase. Journal of Law and Economics 54:S125-S165.

Heller, Michael. 2008. The Gridlock Economy: How Too Much Ownership Wrecks Markets, Stops Innovation, and Costs Lives. Philadelphia: Basic Books.

$\rightarrow$ Hohfeld, Wesley Newcomb. 1917. Fundamental Legal Conceptions as Applied in Judicial Reasoning. Yale Law Journal 26:710-70. 
$\rightarrow$ Holderness, Clifford G. 1985. A Legal Foundation for Exchange. Journal of Legal Studies 14:321-43.

Journal of Legal Studies. 2002. Supplement: The Evolution of Property Rights. 31:S331S672.

$\rightarrow$ Kocourek, Albert. 1920. Rights In Rem. University of Pennsylvania Law Review 68:322-36.

Komesar, Neil K. 1994. Imperfect Alternatives: Choosing Institutions in Law, Economics, and Public Policy. Chicago: University of Chicago Press.

Libecap, Gary D., and Dean Lueck. 2011. Land Demarcation Systems. Pp. 257-95 in Research Handbook on the Economics of Property Law, edited by Kenneth Ayotte and Henry E. Smith. Cheltenham and Northampton, Mass.: Edward Elgar.

$\rightarrow$ McCloskey, Deirdre. 1998. The So-Called Coase Theorem. Eastern Economic Journal 24: 367-71.

$\rightarrow$ Merrill, Thomas W. 1985. Trespass, Nuisance, and the Costs of Determining Property Rights. Journal of Legal Studies 14:13-48.

- 1998. Property and the Right to Exclude. Nebraska Law Review 77:730-55.

$\rightarrow \longrightarrow$. 2009. Accession and Original Ownership. Journal of Legal Analysis 1:459-510.

$\rightarrow$ Merrill, Thomas W., and Henry E. Smith. 2000. Optimal Standardization in the Law of Property: The Numerus Clausus Principle. Yale Law Journal 110:1-70.

$\rightarrow$. 2001a. The Property/Contract Interface. Columbia Law Review 101:773-852.

$\rightarrow \longrightarrow$ 2001b. What Happened to Property in Law and Economics? Yale Law Journal 111:357-98.

- 2007a. The Morality of Property. William and Mary Law Review 48:1849-95.

. 2007b. Property: Principles and Policies. New York: Foundation Press.

Michelman, Frank I. 2005. There Have to Be Four. Maryland Law Review 64:136-58.

$\rightarrow$ Minasian, Jora R. 1975. Property Rights in Radiation: An Alternative Approach to Radio Frequency Allocation. Journal of Law and Economics 18:221-72.

$\rightarrow$ Penner, J. E. 1993. Nuisance and the Character of the Neighbourhood. Journal of Environmental Law 5:1-29.

. 1997. The Idea of Property in Law. Oxford: Clarendon Press.

$\rightarrow$ Polinsky, A. Mitchell. 1979. Controlling Externalities and Protecting Entitlements: Property Rights, Liability Rule, and Tax-Subsidy Approaches. Journal of Legal Studies 8:1-48.

$\rightarrow$. 1980. Resolving Nuisance Disputes: The Simple Economics of Injunctive and Damage Remedies. Stanford Law Review 32:1075-1112.

Posner, Richard A. 1998. Economic Analysis of Law. 5th ed. New York: Aspen Law and Business.

$\rightarrow$ Radin, Max. 1938. A Restatement of Hohfeld. Harvard Law Review 51:1141-64.

$\rightarrow$ Rose, Carol M. 1991. Rethinking Environmental Controls: Management Strategies for Common Resources. Duke Law Journal 1991:1-38.

- 1994. Property and Persuasion: Essays on the History, Theory, and Rhetoric of Ownership. Boulder: Westview Press.

$\rightarrow$. 1997. The Shadow of The Cathedral. Yale Law Journal 106:2175-2200.

$\rightarrow$. 1998. Canons of Property Talk, or, Blackstone's Anxiety. Yale Law Journal 108: 601-32.

Schlag, Pierre. 1989. The Problem of Transaction Costs. Southern California Law Review 62:1661-1700.

Schorr, David B. 2009. How Blackstone Became a Blackstonian. Theoretical Inquiries in Law 10:103-26. 
Schroeder, Jeanne L. 1999. Three's a Crowd: A Feminist Critique of Calabresi and Melamed's One View of the Cathedral. Cornell Law Review 84:394-503.

$\rightarrow$ Schwab, Stewart. 1989. Coase Defends Coase: Why Lawyers Listen and Economists Do Not. Michigan Law Review 87:1171-98.

Smith, Adam. [1762-63] 1978. Lectures on Jurisprudence, edited by R. L. Meek, D. D. Raphael, and P. G. Stein. Oxford: Clarendon Press.

$\rightarrow$ Smith, Henry E. 2003. The Language of Property: Form, Context, and Audience. Stanford Law Review 55:1105-91.

$\rightarrow \longrightarrow$. 2004. Exclusion and Property Rules in the Law of Nuisance. Virginia Law Review 90:965-1049.

- 2005. Self-Help and the Nature of Property. Journal of Law, Economics and Policy 1:69-107.

. 2008. Governing Water: The Semicommons of Fluid Property Rights. Arizona Law Review 50:445-78.

- 2009a. Community and Custom in Property. Theoretical Inquiries in Law 10:5-41. 2009b. Mind the Gap: the Indirect Relation between Ends and Means in American Property Law. Cornell Law Review 94:959-89.

- 2011. Standardization in Property Law. Pp. 148-73 in Research Handbook on the Economics of Property Law, edited by Kenneth Ayotte and Henry E. Smith. Cheltenham and Northampton, Mass.: Edward Elgar.

$\rightarrow$ Stigler, George J. 1961. The Economics of Information. Journal of Political Economy 69: 213-25.

. 1966. The Theory of Price. 3d ed. New York: Macmillan.

$\rightarrow$ Van Zandt, David E. 1993. The Lessons of the Lighthouse: "Government" or "Private" Provision of Goods. Journal of Legal Studies 22:47-72.

Williamson, Oliver E. 1975. Markets and Hierarchies: Analysis and Antitrust Implications. New York: Free Press. 